Attarbiyah: Journal of Islamic Culture and Education

\title{
Implementation Of National Character Education (Study Of Scouting Activities Analysis At Man 2 Karanganyar)
}

\author{
Ahmad Muhtadi \\ Kantor Kementerian Agama Karanganyar \\ taddy_ahmad@yahoo.co.id \\ DOI: 10.18326/attarbiyah.v4i1.41-68
}

\begin{abstract}
This research is aimed to describe various forms of students' character nurturing through scouting activities at MAN 2 Karanganyar. This research also studied a number of constraints emerging within the nurturance of the students' character and efforts made to overcome the constraints. It was a descriptive research study employing a qualitative approach. The subjects were selected using a purposive sampling technique. The data were collected through participatory observation, interviews, and documentation. The data were then analyzed using an inductive analysis technique. The results showed that character building through scouting activities at MAN 2 Karanganyar by maximizing the roles of the scout nurturers as partners or supervisors, gave supports and facilitated students with modern, interesting, and challenging activities. Among the methods used were: the implementation of scouting codes of respects in every activity; learning activities through doing, working in groups, cooperating, and competing; activities in the open air such as camping; rewards in the forms of capacity symbols such as bantara and laksana; and separate units of ambalan for males and females. The constraints emerging were, among others, a lack of teachers' attention to the scouting issues and the great number of students who did not like to join scouting activities. The solution was through inviting all the teachers to willingly contribute to the scouting activities and creating interesting and challenging activities for the students
\end{abstract}

Keywords: character building, students, scouting activities 
Attarbiyah: Journal of Islamic Culture and Education

\section{Introduction}

Character problems and character education are problems that have always been discussed by Indonesian people, especially by education activists. An indication that the issue of character is important is the rampant actions and behavior of the people that are far from the values of noble characters. There are many phenomena in the community that indicate the loss of the noble values of the Indonesian people, such as: honesty, politeness, and togetherness. On the other hand negative behaviors, such as theft, rape, murder, adultery, and drug abuse, all adorn the lives of teenagers, even students in schools in Indonesia.

Character development is one of the national development priorities as outlined in the National Long Term Development Plan (RPJPN) for 2005 - 2025. The priority is expressed in the phrase realizing a noble, moral, ethical, cultured, and civilized society based on the Pancasila philosophy ". As for realizing this goal, one of the efforts that can be done is by strengthening the identity and character of the nation through education. This effort aims to shape and develop Indonesian people who are devoted to God Almighty, obey the rule of law, maintain internal and inter-religious harmony, carry out intercultural interactions, develop social capital, apply the noble values of national culture, and have pride as a nation Indonesia in order to strengthen the spiritual, moral, and ethics of national development (Bappenas, 2009).

\section{Vol. 4 No. 1, 2019}


Attarbiyah: Journal of Islamic Culture and Education

Characters cannot be formed in a short time. Building a nation's character takes a long time and must be carried out continuously. The character that is inherent in the Indonesian people lately does not just happen suddenly, but has gone through a long process. The Indonesian government, represented by the Ministry of Education and Culture, has ceaselessly made efforts to improve the quality of education in Indonesia, but not all have succeeded. Some education observers even argue that the quality of education in Indonesia does not increase, and even tends to decline. One indicator is the declining attitudes and moral behavior of graduates from educational units which increasingly tend to be far from the desired moral values.

The government in building character has a very important role in the nation, especially through the making of laws and regulations that guarantee a more solid and upright national character. Because of the pressure of global norms of life, it is not uncommon for the government's role to be ambivalent. However, unfortunately, the government is not sufficiently aware of this so the government does not develop policies that are pro-character development.

Formal education does have an important role in building the character of the nation, because with education students try to be equipped with a variety of knowledge and skills so they can live in the midst of society. In addition, education also has an important role in fostering a spirit of love for the country and the spirit of patriotism. However, it turns out that in its implementation formal education has not 
Attarbiyah: Journal of Islamic Culture and Education

been able to carry out its role properly. Formal education carried out in Indonesia is more still trapped in the transfer of knowledge so that it is needed a breakthrough in the world of formal education, so that every educational institution is able to play a role in engineering the development of national character.

In order to anticipate this problem, education in Indonesia needs to be taken seriously, for example by being reconstructed so that graduates can be more qualified and ready to face the "world" of the future that is full of problems and challenges and can produce graduates who have attitudes and noble moral behavior. In other words, education must be able to carry out the mission of character building so that students and graduates of educational institutions can participate in filling development in the future without abandoning moral values or noble character. One effort to realize education as above, students or students must be equipped with special education that carries a basic mission in noble moral formation. This kind of education can give direction to students after receiving various knowledge and knowledge in their respective fields of study so that they can practice it in the midst of society while still adhering to the values of universal truth and goodness.

The mission of character building is not only carried out by certain fields of study or subject matter, for example the subject of Religious Education or the Civic Education (PKn) model, but also by other fields of study together. Even so, the two subjects or subject matter such as these 
Attarbiyah: Journal of Islamic Culture and Education

can be used as a basis that is directly related to the development of student character, especially because most of the material in these maps is filled with character values. In addition, religious activities and other activities included in extracurricular activities and forms of habituation in schools can also be used as a means to cultivate students with noble character values.

Character building through extracurricular activities in schools in line with the 11 principles of Effective Character Education. The eleven principles are guidelines for "curriculum integration, extra-curricular activities, maximizing character education outcomes."

The issuance of Law Number 20 of 2003 concerning the National Education System (National Education System Law) reaffirms the functions and objectives of Indonesia's national education. In Article 3 of the National Education System Law, national education functions to develop the capacity and form of dignified national character and civilization in order to educate the nation's life, aiming for the development of potential students to become believers and godly people, noble, healthy, knowledgeable, capable, creative, independent, and a democratic and responsible citizen. Thus, the subjects of Religious Education and Citizenship Education carry out a very noble mission in the development of this nation. Of course all subjects other than the two subjects together have the mission integrated.

The above phenomenon indicates that education that builds moral values or character among students must always get attention. Education at 
Attarbiyah: Journal of Islamic Culture and Education

the elementary level (elementary and junior high school) is a very important place to prepare early on for future generations who will become leaders of our nation in the future. Therefore, all implementers of education at the basic level must have a high level of concern for these moral or character problems, especially the education actors in the school. The next level of education, namely secondary education and tertiary education, also still has to get serious attention in terms of fostering national character, given the incessant external influences that may arise and disrupt the character building of students.

Efforts that can be made to foster the character of students in educational institutions include maximizing the quality of classroom learning and extracurricular activities that support the planting of student character values in schools such as Scout activities. Citizenship Education can be used as a basis for fostering student character, especially in addition to fostering awareness of students to become good citizens so that they can carry out all their duties and functions as citizens. In addition, it also provides an understanding of the importance of understanding their rights and obligations properly so that democratic values and nationalism grow within them.

Among the extracurricular activities that must be in school and have a big role in forming student character is scouting activities. In general, scouting activities that are accommodated in a movement called the Scout movement have several objectives, namely: (1) so that its 
Attarbiyah: Journal of Islamic Culture and Education

members become human beings who have noble personality and character as well as high mental, moral, ethical, and strong beliefs; (2) its members become human beings with high intelligence and skills; (3) its members become human beings who are strong and physically healthy; and (4) its members become Indonesian citizens with the spirit of Pancasila, loyal, obedient to the Unitary State of the Republic of Indonesia, so that they become good and useful members of the community who are capable and capable of carrying out nation and state development. Based on this, it can be understood that scouting activities strongly support the school's efforts in delivering students to noble character.

In order for this activity to be directed, a charter of the scout movement was made which became the basis and foundation for implementing scouting activities in schools. The articles of association of the scout movement were ratified by the Presidential Decree of the Republic of Indonesia Number 24 of 2009 concerning Ratification of the Scout Movement's Articles of Association. In Article 8 of the Presidential Decree, efforts must be made to achieve the objectives of the scout movement. First, instill and cultivate noble mind and character by strengthening mental, moral, physical, knowledge, skills, and experience through religious activities, harmony in religious life, appreciation and practice of Pancasila, concern for fellow life and nature as a whole, and fostering and developing interest in technological progress with faith and piety. Second, fostering and developing love and loyalty to the homeland and nation. Third, fostering and developing unity and nationality. Fourth, 
Attarbiyah: Journal of Islamic Culture and Education

fostering and developing brotherhood and friendship both nationally and internationally. Fifth, grow to the members of self-confidence, attitude, creative and innovative behavior, a sense of responsibility and discipline. Sixth, develop entrepreneurial spirit and attitude. Seventh, fostering and developing leadership. Eighth, fostering, autonomy and autonomy, skills and works.

The built of students' character through scouting activities requires active participation from students. This is so that the internalization of character values in students can run more effectively. This view is supported by the results of research conducted by Agboola and Tsai which states that "Education policy should take the lead to actualize moral education. Parents, teachers, and administrators as stakeholders, should join this camp to encourage students to manifest those good values in their lives.

The results of the research conducted by Kamaruddin state that: the internalization of character values in character education must be outlined in strategic planning and integrated program design. The results of the programs implemented cannot directly change the character of students, but are expected to provide nuances in the atmosphere of learning. Thus, the character education program in the future must be carried out with the support of high commitment. Character habituation programs need to be carried out and the realization of noble character which is the highest goal of the education process must be carried out by 
Attarbiyah: Journal of Islamic Culture and Education

all educational institutions that organize the educational process.

Based on the aforementioned background background, this study seeks to describe: (1) implementation of student character building in extra-curricular scouting activities; (2) character values developed in extracurricular activities of religion, and; (3) supporting factors and inhibiting factors in character building through scouting activities in MAN 2 Karanganyar.

\section{Methodology}

This research is a descriptive study using a qualitative approach. Qualitative research according to Creswell, is an approach to building a statement of knowledge based on a constructive perspective, or based on a participatory perspective. According to Creswell said that "A qualitative approach is one in which the inquirer often makes knowledge claims based primarily on constructivist perspectives or advocacy / participatory perspectives or both."

Determination of research subjects in this study using a purposive technique, with the criteria of people who know, are experienced, and can provide information about planting character values as well as education in MAN 2 Karanganyar, namely principals, teachers, employees, scout coaches, and students at MAN 2 Karanganyar. This research was conducted at the beginning of March until the end of May 2017. The researcher used several techniques to collect data, namely participatory observation, interviews, and documentation. The collected data is then 
Attarbiyah: Journal of Islamic Culture and Education

checked for validity in order to obtain data that can be scientifically accountable with triangulation techniques. The data analysis techniques are inductive analysis techniques with steps of data reduction, data categorization, data display, and conclusion

\section{Discussion}

Implementation of student character building in scouting extra-curricular activities at MAN 2 Karanganyar

MAN 2 Karanganyar, formerly known as MAN Gondangrejo, has a vision of "Islamic secondary education institutions that deliver students who are faithful, devoted, have good character, populist, quality, and care for the environment." In order to realize the vision above, MAN Gondangrejo Karanganyar carry out 8 Missions, namely:

1. Organizing learning and habituation that refers to the Qur'an and the Sunnah of the apostle.

2. Organizing quality education in academic achievement that is oriented towards efforts to cultivate, preserve and not damage the environment.

3. Increasing the professionalism and quality of educators and educators in accordance with the development of the world of education that is environmentally sound.

4. Ensure the implementation of effective, efficient, transparent and accountable management of madrasas.

5. Realizing the madrasa becomes a pride and an inseparable part of 
Attarbiyah: Journal of Islamic Culture and Education society.

6. Realizing cooperation with various parties in order to build, develop the progress of madrasa that is environmentally sound.

7. Realizing the quality of the madrasa environment that is safe, comfortable, beautiful, concerned with the preservation of surrounding natural resources.

8. Familiarize the madrasa community to preserve and prevent pollution and environmental damage

The educational objective of Gondangrejo State Islamic Senior High School is "Developing the potential for intelligence, knowledge, personality, noble character and skills to live environmentally independent life and follow further education".

In its implementation, growing Pancasila values was carried out by returning the Pancasila and Citizenship Education (PPKN) subjects and adding face-to-face hours, from two hours to three hours. Not only in teaching and learning activities, efforts to foster Pancasila values are also manifested in intracurric and extracurricular activities. For extracurricular activities, the Ministry of Education and Culture requires Scout education in schools, from elementary school to secondary school. The first thing that underlies the decision of the Ministry of Education and Culture is the values and forms of scouting activities that are in line with efforts to restore Pancasila values. Second, fostering the attitudes and skills of teenagers through the scout movement has been going well now. In fact, the scout movement has entered the education environment as a whole. 
Attarbiyah: Journal of Islamic Culture and Education

This is indicated by the establishment of front groups in schools, ranging from the level of primary education to secondary education.

A variety of fun and interesting activities can be part of the way the Scout Movement forms the character of the individual. Scouting education is a process of education outside the school environment and outside the family in the form of interesting, fun, healthy, orderly, directed, practical activities carried out in the open with the Basic Principles of Scouting and Scouting Methods (PDK and MK) whose ultimate goal is character formation.

The implementation of character education in scouting extracurricular activities at MAN 2 Karanganyar is by planting and entering eighteen character values into all scouting extracurricular activities, namely: the value of religious character, honest character values, tolerance character values, discipline character values, hard work character values, creative character values, independent character values, democratic character values, curiosity character values, national spirit character values, national love character values, character values respect achievement, communicative character values, peace-loving character values, reading character values, character values care about the environment, social care character values, and character values of responsibility. The implementation of character education in scouting extracurricular activities at MAN 2 Karanganyar is well implemented.

Scouts as one of the extra-curricular activities in schools are very 
Attarbiyah: Journal of Islamic Culture and Education

relevant to national character education as evidenced by the similarity of values of character education with the values of Dasa Dharma, so it is very appropriate that through scouting character education be formed.

The Scout Movement begins with the age of 7 to 25 years as young members, divided into Siaga Scouts (7-10), Penggalang Scouts (11-15), Penegak Scouts (16-20) and Pandega Scouts (21-25). Division of groups based on the development and characteristics of both physical and psychological.

Following are the values of character education: Religious, Honest, Tolerance, Discipline, Hard Work, Creative, Independent, Democratic, Curiosity, National Spirit, Love of the country, Respect for achievements, Friendly / Communication, Love Peace, Love to Read, Care Environment, Social Care, and Responsibility.

Whereas the values in the Dasa Dharma Scout include: Faith in the Almighty God; Love of nature and affection of fellow humans, polite Patriots and knights; Obedient and like to discuss; Willing to help and be steadfast; Diligent, skilled, and happy; Savings, careful and simple; Discipline, brave and loyal; Responsible and trustworthy; Holy in thoughts, words and deeds.

Scout extracurricular in MAN 2 Karanganyar is a compulsory extracurricular activity that must be followed by all students of MAN 2 Karanganyar. For that, of course scout coaches must also have thorough preparation in conducting quality scouting activities. According to Muh. Arif Ruslan, S. Pd.I, as the coach of the male unit, the implementation of 
Attarbiyah: Journal of Islamic Culture and Education

scouting education in MAN 2 Karanganyar has used the syllabus. Syllabus is made at the beginning of the service period. The RPP was submitted to the Ambition Board which was later implemented in the work program.

In principle, the pattern of guiding Penegak scout is from, by, and for the enforcers themselves so that the coach in carrying out his coaching is only a motivator, motivator, and instructor to the scout members who here have been confirmed as the Ambulance Council (DA). While in the process of processing the organization that is in direct contact with students of class $\mathrm{X}$ is the Ambition Board (DA) itself. They are the ones who are trying to implement the scouting activities that will be held so that the RPP that will be made is adjusted to what training activities they will hold for class X MAN 2 Karanganyar Ambalan Cakra Sakti with the support of adults namely scout coaches.

Scout coaches as adults who are directly involved in the process of scouting education certainly have an important role, so that through this role what is the goal of conducting surface activities can be realized. Moreover, MAN 2 Karanganyar is a school characterized by Islam, and in carrying out activities it must not deviate from Islamic values. It was also in line with the first norm which became a code of honor for scouts, namely fear of God Almighty. Of course the activities that will be held will strengthen the religious values of each of its members.

The role of scout coaches in shaping characters in MAN 2 Karanganyar. According to Muh. Arif Ruslan, S. Pd.I, as the supervisor of 


\section{Attarbiyah: Journal of Islamic Culture and Education}

the male unit, that the role of the coach is as a partner. Because the motto in the enforcer is from, by and for the enforcer himself. According to Ninuk Indarwati, S.Pd, as the coach of the female unit, the role of the coach is to instill a korsa / togetherness in students. To instill character values pesonalitas students can through planting korsa soul because it can thus grow a sense of kinship among fellow members so that no one will feel like a boss or subordinate. If the students in general the role of the coach is how can students comply with their learning contract.

The role of scout coaches in MAN 2 Karanganyar is as partners. Partners here are as counselors and advisors when a problem occurs in an organization that cannot be solved by students themselves. It is not the role of boss or subordinate, but the role of the elder brother towards his younger siblings so that when students face a problem they will not be reluctant or hesitant to tell and consult on the problems at hand.

The role of scout coaches in MAN 2 Karanganyar is as partners. Partners here are counselors and advisors when a problem occurs that cannot be solved by students themselves. It is not the role of boss or subordinate, but the role of the elder brother towards his younger siblings is that when students face a problem they will not be able to relate to the problem.

From the cross check observation data can be seen that the coach has carried out his role as a partner. To prepare for the Community Service Campaign (KBM) there are many things that must be prepared by the committee (Sangga Kerja / Sangker). The many things that must be 
Attarbiyah: Journal of Islamic Culture and Education

prepared of course also make Sangker encounter many problems, which makes Sangker need to consult with the coaches through camp preparatory meetings.

Through these meetings, various characters who try to cultivate, for example, how to express opinions, respect other people's opinions, are democratic, tolerate, do not impose opinions, accuracy, and so on. The results of the distribution of the questionnaires that were given openly showed that most students who participated in Scouting activities considered the pattern of coaching in scouts, especially the enforcers to be like their brothers and sisters. Only a small number think that is not the case because basically they do not like scouting activities.

Based on the explanation from Muh. Arif Ruslan, S. Pd.I, it is known that one of the methods of education in scouting is learning by doing. So, they have to be more active in making their own efforts in the form of their activities. For example outdoor activities such as rigging they do themselves and the coach only gives an example. According to Sri Sugiyarti, as the coach of the women's unit, the form of active participation in the Ambalan Council can be built and improved when it becomes a committee / Sangga Kerja for an activity. In class X students in general to increase their active participation by conducting activities that interact with nature, in groups, learning by doing, etc.

In addition to learning by doing, the way to guide students to increase their active participation is to form a Work Sangga or committee 
Attarbiyah: Journal of Islamic Culture and Education

for certain activities against scouts in MAN 2 Karanganyar so that they also have a negative assessment in response to these activities.

Associated with preparing students to be ready to take part in the scouting process at MAN 2 Karanganyar, Muh. Arif Ruslan, S.Pd.I as the coach of the male unit, stated that students were prepared by holding an Upright Basic Orientation (ODT). Through this activity various interesting activities were given as well as brief material related to the introduction of MAN 2 Karanganyar scouts or the Cakra Sakti Ambalan. With this activity, students who have just moved from junior high school to high school from raisers to enforcers will be more familiar with scouts. In each exercise, students are guided by their siblings or Board of Ambitions in preparing activities. Sri Sugiyarti, S.Pd.I, as the supervisor of the women's unit stated that: "In an activity the coach will form a committee / Sangga Kerja (Sangker) with various stages. From this anchor it will be planned an activity both ODT, and others. Whereas if for students, the preparation will be assisted by the Board of Ambitions ". Here the students who had just moved from the raisers to the prospective enforcers were given basic training for three days to introduce the MAN 2 Karanganyar Cakra Sakti Scout Scout so that for the next year they would have an idea of what scouts in MAN 2 Karanganyar were like. This will make it easier for students to take part in scout extracurricular activities which are carried out compulsorily by the school.

The way scout builds and increases student active participation is learning by doing. So, they have to be more active in making themselves in 
Attarbiyah: Journal of Islamic Culture and Education

the form of their activities. For example outdoor activities such as rigging they do themselves and the coach only gives an example. According to Sri Sugiyarti, S.Pd.I, as the coach of the women's unit, a form of active participation in the Ambalan Council can be built and improved when it becomes a committee / Sangga Kerja for an activity. In class X students in general to increase their active participation by conducting activities that interact with nature, in groups, learning by doing, etc.

In addition to learning by doing, the way to guide students to increase their active participation is to form a Sangga Kerja or committee for certain activities such as a camp held on May 26-29 2017 at the Cakra Pahlawasri Delingan Karanganyar Campsite. Through this camp activity, DA becomes active in the established committee to prepare and carry out activities. While for class $\mathrm{X}$ students to be active in participating in the camp activities. Through camp activities many characters can be developed by the coach, including the character of the DA or Sangker, namely cooperation, cohesiveness, mutual respect, and leadership. As for students, namely kinship among neighbors, cohesiveness, independence, love of nature, discipline, cooperation, and others.

A good form of active student participation certainly needs to be supported by good responses or responses from scout coaches so that students continue to be motivated to try to do their best. How to guide scouts in giving responses or resons to students who participate actively or not. According to Muh. Arif Ruslan, S. Pd.I, for those who actively 
Attarbiyah: Journal of Islamic Culture and Education

participate, they definitely want to become an Ambition Board by getting rewards in the form of General Skills Signs (Bantara and Laksana). Less active students will get sanctions from the school in the form of points or reprimands. According to Muh. Arif Ruslan, S. Pd.I, rewards for active students are included in various activities or competitions held by Kwaran, Kwarcab, and Kwarda. For those who are less active, of course, they will get an unfavorable assessment so that the coach tries to build the character of discipline and responsibility so that activeness will occur in participating in scouting activities, so that he is not lazy anymore.

The scout coach's response to active students is to provide a reward in the form of TKU (General Skills Sign) after completing the SKU (General Skills Requirements) in the form of Bantara and Laksana and TKK (Sign of Special Skills) as well as Ambush Ambassadors. Based on the cross check observation data so far, there are 150 people who get Bantara TKU for class X. Other rewards in the form of Ambassadors Ambassadors sending as representatives in participating in a race such as the Joko Songo Odyssey race which is held every December followed by all SMA / MA / SMK in Karanganyar Regency get 4 trophies, for Cultural Exploration to get 3 trophies from 6 trophies contested on Sunday, May 26, 2017 and so on.

From this activity can be formed the character of hard work, cooperation, cohesiveness, leadership, religious, caring, and kinship to the students themselves from the training process until the competition activities are finished. As for students who are not active, they will get 
Attarbiyah: Journal of Islamic Culture and Education

reprimands either through scout coaches or by Student Waka, which are forwarded to their respective Classes, get transactional points, do special treatment by putting forward some of the values that are not embedded in students, for example like to play truant or not fully dressed, then more intensive coaching is done so that the sense of responsibility and discipline can be more formed. This is reinforced by the statement of homeroom $\mathrm{X}$ in the interview stating that through routine scout training activities they became more disciplined and responsible learning.

According to the explanation from Sri Sugiyarti, S.Pd.I, the strategy of planting values so that character formation in students is to pay attention to the five development areas. The area is spiritual, emotional, social, intellectual, and physical in testing SKU. Another strategy is to appreciate Tri Satya and practice Dasa Dharma in every activity. According to Ninuk Indarwati, S.Pd., for the Ambalan Council, the strategy used to plant character values for students is to instill a korsa soul so that they will be able to solve various problems that arise in the organization. From here they also learn to develop leadership. The strategy used in class X students is to train discipline so that later they become children who are more selfaware and more able to organize themselves.

Indeed, to instill discipline in students is not an easy thing, especially scouts as an organization are underestimated by many students. This makes them lazy to take part in the scout routine which is held every Friday. This statement is in accordance with the results of an open data 
Attarbiyah: Journal of Islamic Culture and Education

questionnaire in which only about $10 \%$ of 200 students stated that they were truant more than attending when routine scout training activities were held on the grounds that scouts were considered insignificant, tiring activities, boring activities and did not like scouts . With such conditions, it is not easy for scout coaches to shape the character of students so that a way is needed to overcome them.

Many activities can be carried out to carry out character education and educate discipline through scouting activities in MAN 2 Karanganyar, for example by lines lined up and educating respect for people with deliberation. (the results of interviews with Sri Sugiyarti dated May 6, 2017). The way scout coaches carry out character education through scouting activities is through various activities such as shelter deliberations and work-friendly discussions. Through various deliberation activities there are many characters that can be formed by the coach, among others democratic, respecting the opinions of others, accepting criticism given, and so forth. Another way is through mentoring students or class $\mathrm{X}$ students who have more interest in scouts. This will facilitate the coach in carrying out cadre, planting values, giving skills and knowledge. In addition, another way is to instill a family spirit and concern so that when students have passed the mentoring process in running the organization of their active siblings, it can still be done.

Evaluation of the implementation of character education is done by assessing directly through observation, this is done by incorporating elements of character education. Assessment is done through observation 
Attarbiyah: Journal of Islamic Culture and Education

of student attitudes in their daily lives, including: a) the attitude of students with teachers, principals, school employees, and fellow students; b) student obedience in complying with school rules; c) discipline in prayer on time and not late when entering class; d) discipline in participating in extracurricular activities.

From the explanation above, it was clear that scouting activities carried out at MAN 2 Karanganyar had been on the right tract in accordance with what was expected by the government as stated in the Scout Movement Anggara (Republic of Indonesia Presidential Decree No. 24 of 2009), namely growing students' noble character while strengthening mental, moral, physical, knowledge, skills, and experience. This is also one method in order to facilitate students to develop values and morals and characters, especially intelligent, skilled, and responsible characters (Kirschenbaum, 1995: 159)

In supporting the scouting education process, the right method is needed so that the objectives of the education can be achieved. The right method also needs to be supported with the right media so that the results achieved are also maximal.

This is consistent with Dewey's constructivism learning concept which states that "students construct their own knowledge by testing ideas based on prior knowledge and experience, applying these ideas to a new situation, and integrating new knowledge gained with pre-existing intellectual constructs".

\section{Vol. 4 No. 1, 2019}


Attarbiyah: Journal of Islamic Culture and Education

The findings are supported by the results of research conducted by Prestwich in his research entitled "Character Education in America's Schools". The results of the study show that character education is a complex problem that continues for generations. The school has a big responsibility to teach it. Teachers as the spearhead of education in schools must be able to show attitudes and behaviors that can be used as pilot models for students. In order for the program to run effectively, the school needs to involve all stakeholders in carrying out the character education.

Supporting and Inhibiting Factors in Forming Student Character through Scouting Extracurricular Activities

Supporting factors in building the character of students through scouting extracurricular activities are strong support from parents of students. The majority of parents support scouting activities which are followed by their sons and daughters as soon as they enter class X at MAN 2 Karanganyar, which requires all students of class $\mathrm{X}$ to take part in the scouting extracurricular activities. The support provided by parents is in the form of willingness to pick up their children after the activities and material support in the form of funding when their children participate in the camp activities.

In addition to supporting factors, there are many obstacles faced by scout coaches in MAN 2 Karanganyar in order to foster student character so that it takes more struggle and effort to achieve the goal of scouting education itself. According to the presentation of Sri Sugiyarti, S.Pd.I, the 
Attarbiyah: Journal of Islamic Culture and Education

first obstacle was the lack of support from the school in conducting scouting activities. Second, there are still many parties who look to the scouts that their activities are only a form of waste. In fact, there are things that are expected from scout extracurricular compared to other extracurricular activities.

From the narrative of two scout coaches at MAN 2 Karanganyar, it can be seen that there are several obstacles encountered by scout coaches when character education is instilled through scouting activities. These obstacles include lack of support from the school itself in conducting leadership activities, not only students but also some teachers who see scouts with one eye, as well as differences in the characteristics of each of the various children. Then based on checking the results of observations of researchers as participants is that it is true that the obstacles presented by the two speakers often appear during the educational process. For example, differences in the characteristics of diverse students actually give scouting coaches their own experience in dealing with such students so that when these problems occur again, then past experiences can be used as learning in the face of problems at this time.

This finding supports the results of Adeyemi, Moumakwa, and Adeyemi's research which concluded that an assessment of active student involvement in learning is important to build students' character. Character learning must be done with a holistic method and carried out by involving all school stakeholders.

\footnotetext{
64 Vol. 4 No. 1, 2019
} 
Attarbiyah: Journal of Islamic Culture and Education

Related to the obstacles above, various efforts have been made to overcome them. Efforts made in scouting activities at MAN 2 Karanganyar are based on scouting guidance with sincere intentions, not giving up and discouraged. Because if the personal and organizational constraints can be overcome, the process of planting character values can also be maximized. Another effort is that students are enthusiastic in participating in scouting activities with a special / personal approach, especially for female students. The problems that arise are resolved by consensus agreement. Various efforts carried out must still be adapted to existing conditions.

In general, the results of character planting carried out through scouting extracurricular activities have been able to change the character of students in the class. Students become more disciplined and responsible. This is in line with the opinion of Berkowitz (2012) which states that effective character education will be able to "impacting school educational systems at both the micro and macro levels."

\section{Conclusion}

Based on the results and discussion of the research as described above, several simulations can be presented as follows. First, the role of scouting activities in shaping character in students is carried out through the role of scout coaches as partners namely as mentors, providing support and facilitating students with activities that are modern, interesting, and challenging. While the implementation of the organization's wheels and activities is submitted by the legislators themselves based on the motto of 
Attarbiyah: Journal of Islamic Culture and Education

the enforcer from, by, and for the enforcer. The method of education in scouting carried out by scout instructors at MAN 2 Karanganyar included: the practice of scout honor codes at each activity; learning activities while doing, grouping, working together, and competing; open-air activities such as professions; awards in the form of skills and skills; and separate units of male and female shelter.

Second, the obstacles that arise in fostering the character of MAN 2 Karanganyar students through scouting activities include the lack of attention from the school, especially the teachers, to the problem of scouts, and the many students who do not like to participate in scouting activities. The effort of scout coaches in facing obstacles encountered in MAN 2 Karanganyar is to invite teachers to support scout activities with sincere intentions, then create activities that attract and challenge students

\section{Bibliography}

Adeyemi, Michael Bamidele. Tshiamisho Violet Moumakwa, and Deborah Adeninhun Adeyemi. 2009. Teaching Character Education Across the Curriculum and the Role of Stakeholders at the Junior Secondary Level in Botswana. Journal of Social Sciences Education Vol. 3 No. 2, pp: 97-105, http://www.proquest.umi.com accesed on 12 December 2017

Agbola, Alex, and Kaun Chen Tsai. (2012). Bring Character Education into Classroom. European Journal of Educattional Research Vol. 1, No. 2 (2012), pp: 163-170, http://www.proquest.umi.com accesed on 12 December 2017 
Attarbiyah: Journal of Islamic Culture and Education

Berkowitz, M. (2012). Understanding Effective Character Education. The Literacy and Numeracy Secretariat Capacity Building Series.

PSMP Division Ministry of Educational and cultural Affairs . (2010). Pendidikan Ka-rakter Terintegrasi dalam Pembelajaran di Sekolah Menengah Pertama. Jakarta: PSMP Division Ministry of Educational and cultural Affairs.

Echols, M. John \& Shadily, H. (1995). English-Indonesia Dictionary: An English-Indone-sian Dictionary. Jakarta: PT Gramedia. Ed. XXI.

Kak Sam Rizky. (2012). Buku Wajib Tunas, Mengenal Pramuka Indonesia, (Yogyakarta: Jogja Bangkit Publisher, 2012) pp. 52-54

Kamaruddin SA. (2012). Character Education and Students Social Behavior. Journal of Education and Learning. Vol.6 (4) pp. 223-230) ttp://journal.uad.ac.id/index.php/EduLearn/article/download/16 6/pdf. (diakses 22 Mei 2018).

Presidential decree no. 24 of 2009 concerning ratification of the articles of association of scout movement

Koesoema, Doni. (2007). Pendidikan Karakter: Strategi Mendidik Anak di Zaman Glo-bal. Jakarta: Grasindo. First Ed.

National Scout Quartet, Manual for advanced level scout instructor, (Jakarta: National quartet publisher, 2011) p.15.

Lickona, Thomas. (1991). Educating for Cha-racter: How Our School Can Teach Res-pect and Responsibility. New York, To-ronto, London, Sydney, Aucland: Bantam Books.

O'Connor, Ann., Amber Olson, Natalie Hoff \& Reece L. Peterson. 2014. "Character Education". Strategy Brief 2014. University of NebraskaLincoln. 
Attarbiyah: Journal of Islamic Culture and Education

Pemerintah Republik Indonesia. (2010). Ke-bijakan Nasional Pembangunan Karakter Bangsa Tahun 2010-2025. Jakarta: Pu-sat Kurikulum Balitbang Kemdiknas.

Prestwich, Dorothy L. (2011). Character Education in America's Schools. Journal of School Community Vol. 4 No. 1, 2011, pp: 139-150, http://www.proquest.umi.com diakses pada 12 Desember 2016

Pusat Bahasa Departemen Pendidikan Nasional. 2008. Kamus Bahasa Indonesia.Jakarta: Pusat Bahasa. Cet. I.

Ryan, Kevin \& Bohlin, K. E. (1999). Building Character in Schools: Practical Ways to Bring Moral Instruction to Life. San Francisco: Jossey Bass.

Tim Esensi. (2012). Mengenal Gerakan Pramu-ka. Jakarta: Esensi, Erlangga publisher division.

Zamroni. (2011). "Strategi dan Model Imple-mentasi Pendidikan Karakter di Sekolah" on Darmiyati Zuchdi et all. (ed.). Pendidikan Karakter dalam Perspektif Teori dan Praktik. Karanganyar: UNY Press.

68 Vol. 4 No. 1, 2019 